\title{
Refractory Esophageal Strictures: What To Do When Dilation Fails
}

\section{Petra G. A. van Boeckel, MD, PhD* Peter D. Siersema}

\author{
Address \\ "Department of Gastroenterology and Hepatology, HP: F02.618, University Med- \\ ical Center, Heidelberglaan 100, 3584CXUtrecht, Netherlands \\ Email: p.g.a.vanboeckel@umcutrecht.nl \\ Published online: 4 February 2015 \\ (C) The Author(s) 2015. This article is published with open access at Springerlink.com
}

This article is part of the Topical Collection on Esophagus

Keywords Refractory benign esophageal stricture - Dysphagia - Dilation - Incisional therapy - Intralesional steroid injection - Self-expandable plastic stent - Self-expandable metal stent - Biodegradable stent placement .

Esophagectomy

\section{Opinion statement}

Benign esophageal strictures arise from a diversity of causes, for example esophagogastric reflux, esophageal resection, radiation therapy, ablative therapy, or the ingestion of a corrosive substance. Most strictures can be treated successfully with endoscopic dilation using bougies or balloons, with only a few complications. Nonetheless, approximately one third of patients develop recurrent symptoms after dilation within the first year. The majority of these patients are managed with repeat dilations, depending on their complexity. Dilation combined with intra lesional steroid injections can be considered for peptic strictures, while incisional therapy has been demonstrated to be effective for Schatzki rings and anastomotic strictures. When these therapeutic options do not resolve the stenosis, stent placement should be considered. Self bougienage can be proposed to a selected group of patients with a proximal stenosis. As a final step surgery is an option, but even then the risk of stricture formation at the anastomotic site remains. This chapter reviews refractory benign esophageal strictures and the treatment options that are currently available.

\section{Introduction}

Benign esophageal strictures are caused by a diversity of esophageal disorders or injuries, for example gastroesophageal reflux, radiation therapy, ablative therapy, or the ingestion of a corrosive substance. In addition, stricture formation may be a complication of esophageal resection with gastric tube formation $[1,2]$. More than 80-90 \% of esophageal strictures can be treated successfully with endoscopic dilation using Savary bougies or balloons. Esophageal dilation is a procedure with a very low rate of serious complications, mainly bleeding and 
perforation [3-5]. Unfortunately, approximately one third of patients develop recurrent dysphagia after dilation within the first year. The majority of these patients are managed with repeat dilations, depending on their complexity $[2,6]$.

Simple strictures are considered to be short, focal, straight, and to allow passage of a normal diameter endoscope. Examples include Schatzki rings, esophageal webs, and peptic strictures [7]. Overall, one to three dilations are sufficient to relieve dysphagia in simple strictures. Only 25-35\% of patients require additional sessions, with a maximum of five dilations in more than $95 \%$ of patients [4]. Complex strictures are usually longer $(>2 \mathrm{~cm})$, angulated, irregular, or have a severely narrowed diameter. These strictures are more difficult to treat and have a tendency to be refractory or to recur despite dilation therapy. A fair number of complex strictures include circular, anastomotic strictures in the absence of endoscopic evidence of inflammation $[8 \bullet \bullet, 9]$. Other etiologies include radiation induced strictures, caustic strictures, and photodynamic therapy induced strictures [7].

Dysphagia is the most common symptom in patients with a benign esophageal stricture. Remarkably, most patients do not experience severe weight loss, as can be seen in malignant esophageal strictures [9]. Treatment aims to relieve symptoms, with the avoidance of complications and the prevention of recurrences. Still, dilation is the first line option to treat benign esophageal strictures. When strictures are refractory or recur, dilation therapy combined with steroid injections, incisional therapy, stent placement, self-bougienage, or surgery can be considered [10]. According to the Kochman criteria, refractory or recurrent strictures are defined as an anatomic restriction because of a cicatricial luminal compromise or fibrosis resulting in clinical symptoms of dysphagia in the absence of endoscopic evidence of inflammation. This may occur as the result of either an inability to successfully remediate the anatomic problem to a diameter of at least $14 \mathrm{~mm}$ over five sessions at two-week intervals (refractory); or as a result of an inability to maintain a satisfactory luminal diameter for four weeks once the target diameter of $14 \mathrm{~mm}$ has been achieved (recurrent). This definition is not meant to include patients with an inflammatory stricture (which will not resolve until the inflammation subsides), or those with a satisfactory diameter but having dysphagia on the basis of neuromuscular dysfunction (for example those with dysphagia due to postoperative and/or postradiation therapy) $[8 \bullet \bullet]$.

\section{Treatment of benign esophageal strictures}

\section{Dilation}

The first step in managing benign esophageal strictures remains dilation with an inflatable balloon or a (Savary) bougie $[4,9,11]$. In the literature, no differences have been shown between balloon and bougie dilation in relief of dysphagia and/or recurrence of dysphagia. Also no differences have been shown in the risk of major complications [12-14]. Major complications include perforation, bleeding, and bacteremia. Perforation risk varies between $0.1 \%$ and $0.4 \%$ [11]. Although the majority of patients are effectively treated with up to five dilations, approximately $10 \%$ of patients need ongoing dilations to become dilation free $[8 \bullet \bullet, 15]$. In order to reduce the number and burden of endoscopic dilations to become dysphagia free, various endoscopic treatment options have been suggested.

\section{Dilation combined with steroid injection}

Adding steroid injection to endoscopic dilation into the stricture followed by dilation to avoid recurrent dysphagia has been reported to prevent stricture recurrence. This method, advocated since 1966, has shown encouraging results in patients with peptic strictures [16]. However, most of these studies were small and uncontrolled [17-19]. Randomized trials are unfortunately limited and small-sized [20-22]. Camargo, et al., randomized 14 patients with corrosive 
strictures allocated to steroid injection or placebo [20]. These authors did not find a difference in dilation frequency or recurrent dysphagia between the two groups. In another randomized trial, 21 patients with strictures of different etiologies were included. An increase in the dysphagia free period and periodic dilation index was reported in the steroid arm, but there was not a difference in the total number of dilations. Another study demonstrated a decrease in mean dilation frequency in patients with peptic strictures, from six dilations in the control group to two dilations in the steroid group after one year follow up [21]. Ramage, et al., performed a randomized trial comparing dilation to intralesional 4-quadrant injection of triamcinolone injections [22]. Thirty patients with peptic strictures with recurrent dysphagia after at least one dilation session were included. They concluded that dilation combined with steroid injection and gastric acid suppression therapy reduced the number of repeat dilations and the dysphagia free period, with re-dilation rates of $13 \%$ in the steroid group versus $60 \%$ in the control group $(p=0.01)$.

Hirdes, et al., recently evaluated the efficacy of intralesional triamcinolone injections combined with endoscopic dilation in a relatively large group of patients with anastomotic strictures [23•]. A total of 60 patients with untreated cervical anastomotic esophageal strictures after esophagectomy with gastric tube reconstruction and dysphagia for at least solid food were enrolled and randomized to dilation with or without steroid injections. They concluded that adding intralesional steroid injections to Savary dilation in patients with untreated benign anastomotic esophageal strictures did not result in a clinical benefit. Furthermore, an increased incidence of candida esophagitis was found in the remaining esophagus proximal to the anastomosis.

In conclusion, there is evidence that steroid injection in combination with dilation is able to reduce the risk of recurrent dysphagia in refractory benign esophageal strictures of peptic origin. Nonetheless, this result comes from various small-sized studies with poorly defined patient populations. Furthermore the optimal injection dose, technique and frequency remain to be determined. On the contrary, adding steroid to dilation was not found to be effective in anastomotic strictures. The pathogenesis of anastomotic strictures differs from that of peptic strictures, in that the former is due to ischemia whereas the latter develops as a result of inflammation and ulceration from reflux of gastric acid [24]. Steroids are suggested to locally inhibit the inflammatory response, resulting in a reduction of collagen formation [22].

Incisional therapy with a needle knife was first reported for the treatment of Schatzki rings $[25,26]$. Subsequently, incisional therapy added to balloon dilation, or incisional therapy using a polypectomy snare with additional argon plasma coagulation, were shown to be effective in a small series of patients with anastomotic strictures, without the occurrence of complications [27-30]. Hordijk, et al., included 20 patients with anastomotic strictures that were refractory to dilation, and demonstrated that incisional therapy was safe and effective in simple, short strictures $(<10 \mathrm{~mm})$ [31]. In another study, 24 patients with anastomotic strictures without previous dilation were included. They were treated with endoscopic incisional therapy applying a transparent hood on the tip of the endoscope to enhance control and safety. After two years of follow up 
$87.5 \%$ of the patients were still dysphagia free after one session [32]. In 2009, Hordijk, et al., randomized 62 patients with a primary anastomotic stricture after esophagectomy (who were not previously treated with dilation therapy), to Savary dilation or electrocautery incision. No significant difference in clinical success rates were detected between the incisional therapy and dilation therapy arms [33]. Furthermore no complications were observed after incisional therapy. So, incisional therapy can be considered as an alternative treatment in patients with a (relatively) short stenosis (Fig. 1).

Dilation of an esophageal stricture with a balloon or a bougie is usually done for a period of a few seconds or some minutes. It can, however, be imagined
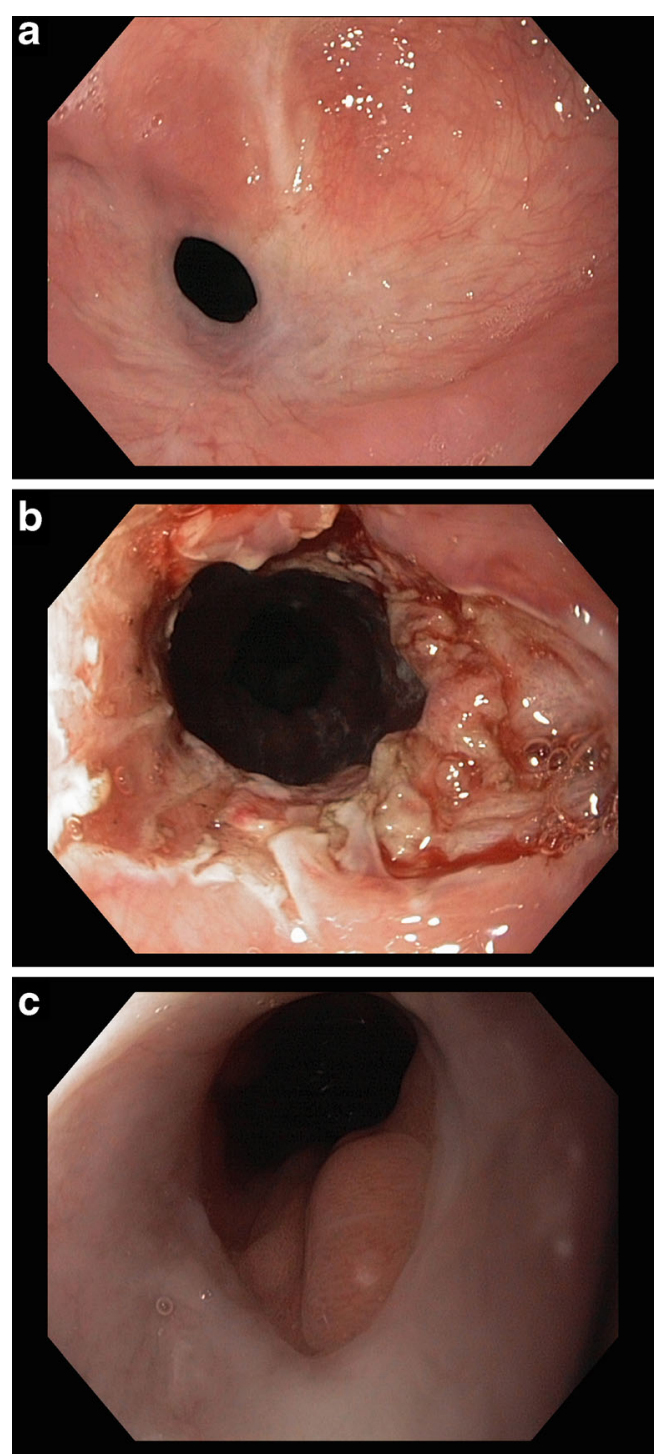

Fig. 1. Endoscopic view of. a Anastomotic stricture. b Directly after incisional therapy. c After long term follow up. 
that if the dilator can be kept in place for a longer time, the benefits of dilation may be longer lasting. In the past few years, temporary stent placement has increasingly been used for refractory benign esophageal strictures. Selfexpandable plastic stents (SEPS) are FDA approved for this indication, and have been used $[34,35]$. Partially and fully covered self-expandable metal stents (SEMS), although not FDA approved, are also frequently used to treat benign esophageal strictures. An alternative for SEPS and SEMS is the biodegradable stent [36], which has the advantage of not requiring removal.

\section{Self-expandable metal stents (SEMS)}

Uncovered SEMS were initially used for the treatment of refractory benign esophageal strictures [37-41]. In more recent years, partially or fully covered SEMS have become available and are now commonly used for this indication $[35,40,42-44]$. One of the major drawbacks of uncovered and partially covered SEMS, is that they are associated with a relatively high complication rate, mostly due to hyperplastic tissue ingrowth through the stent mesh resulting in embedding of the stent in the mucosa [45]. The complication rate of uncovered or partially stents has been reported to be as high as $80 \%$. The most common complications of these stents is indeed new stricture formation due to tissue ingrowth, but also stent migration, pain, gastroesophageal reflux if the stent is positioned across the gastroesophageal junction, and fistula formation [46]. Tissue ingrowth consists histologically of granulation tissue, but reactive hyperplasia and fibrous tissue are also seen [47]. Tissue reaction often results in recurrent dysphagia and may hamper stent removal. On the other hand, particularly minor tissue ingrowth may also reduce the risk of stent migration (only $12 \%$ vs. $36 \%$ for fully covered SEMS) [35, 48, 49•, 50, 51]. The risk of tissue ingrowth increases with stenting time, but can already be seen after one to four weeks. Tissue ingrowth can successfully be treated with the stent-in-stent method described by Hirdes, et al. Using this technique a fully covered stent is placed inside the previously placed embedded stent [49•]. The fully covered stent should have a length that at least overlaps and to have a size that is equal, or slightly larger than, the initially placed partially covered stent. Over a period of 10-14 days pressure necrosis of the hyperplastic tissue occurs as a result of friction. Hereafter, both stents can usually easily be removed.

To overcome the problem of stent ingrowth, fully covered stents (SEMS or SEPS) seem preferable for benign esophageal strictures. Currently, data on the use of fully covered SEMS is limited. In the first study performed by Eloubeidi, et al., a total of 36 stents were placed in 31 patients over a period of 16 months. A clinical success rate of $29 \%$ was reported. A total of $47 \%$ of these patients had no recurrence of dysphagia [48]. Bakken, et al., performed a retrospective study including seven patients with a refractory stricture. Stent migration occurred in more than half of the patients. None of the patients were treated successfully [52]. In 2011, Eloubeidi, et al., included 10 patients with a benign refractory esophageal stricture. A clinical success rate of $21 \%$ was reported, with a migration rate of $10 \%$ [53]. A new generation of fully covered SEMS, the fully covered Wallflex (Boston Scientific, Natick, MA), was recently evaluated by Hirdes, et al. They included 15 patients with a refractory benign esophageal stricture. The migration rate was $35 \%$, while tissue overgrowth was seen in $20 \%$ of patients. Recurrent dysphagia occurred in all patients after a median of only 15 days after stent removal. These disappointing results were however most likely due to the highly refractory patient population in this study [54]. 


\section{Self-expandable plastic stents (SEPS)}

SEPS have been proposed as an alternative to SEMS to minimize hyperplastic tissue reflection. In 2010, Repici, et al., performed a pooled data analysis of all available studies on the use of SEPS for benign esophageal strictures. A total of 130 treated patients were included from 10 studies. Stent placement was technically successful in $98 \%$ of the patients. In $52 \%$ of patients no further dilations were required after a median follow up of 13 months after stent removal. Median stenting time in these studies was not reported. In patients with a proximal stricture the success rate was somewhat lower (33\%). As can be expected, due to the fully covered stent design, a relatively high percentage $(24 \%)$ of stents migrated within four weeks, resulting in a high rate of endoscopic re-interventions ( $21 \%$ ). Major complications were seen in $9 \%$ of patients. One patient died of massive bleeding [55]. More recently, Ham, et al., published an updated systematic review. A total of 172 patients with a benign esophageal stricture were included and treated with SEPS. They found a technical success rate of $98 \%$ and a clinical success rate of $45 \%$ with a rate of early stent migration of $31 \%$ [56]. It can be concluded that SEPS are effective for the treatment of refractory esophageal strictures, but the design needs further improvement to reduce the risk of migration. Moreover, the stent has a high radial and axial force, which may be the cause of an increased risk of stentrelated complications to the esophageal wall, for example severe bleeding.

In general, more studies are needed to compare different stent designs headto-head for the treatment of benign esophageal strictures. An alternative treatment option that has recently been introduced is the placement of a biodegradable stent (Fig. 2). Van Boeckel, et al., compared biodegradable stents with SEPS, i.e., Polyflex stent (Boston Scientific, Natick, MA), in a nonrandomized head-to-head comparison. They found that both SEPSs and biodegradable stents provided long-term relief of dysphagia in $30 \%$ and $33 \%$, respectively, of patients with a refractory esophageal stricture. However, biodegradable stents require fewer procedures than SEPSs [57•].

\section{Biodegradable stents}

Only a small number of cohort studies on the use of biodegradable stent placement in the esophagus have been published, with only a few studies

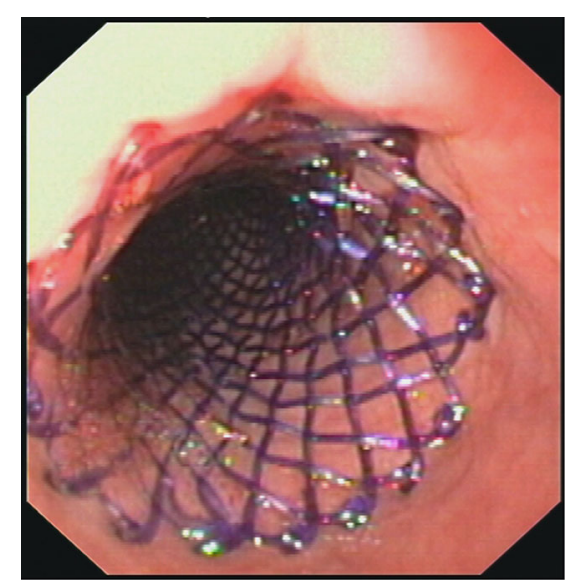

Fig. 2. Endoscopic view of a peptic stricture with an expanding 
including 10 or more patients [36, 57•,58-66]. Repici, et al., included over 30 patients with a refractory benign esophageal stricture and placed an Ella BD stent (Ella CS, s.r.o., Czech Republic). Complete relief of dysphagia was reported in $43 \%$ of patients after a median follow up of 53 weeks [36]. In this study, eight ( $26 \%$ ) patients had recurrent dysphagia resulting from a recurrence of the stricture. No major complications were seen. In the above-mentioned study, van Boeckel, et al., reported complete relief of dysphagia in $33 \%$ of patients treated with a biodegradable stent after a median of 166 days. In this study, major complications occurred in four $(22 \%)$ patients (two hemorrhage and two severe retrosternal pain) [57•]. Ibrahim, et al., included 20 patients treated with an Ella BD stent. Half of them needed one or more additional procedures for recurrent dysphagia after six months of follow up [64]. Van Hooft, et al., also concluded that placement of an Ella BD stent was an effective one step treatment in $60 \%$ ( 6 of 10), of patients with an anastomotic stricture in the esophagus. No major complications were reported [66]. The other $40 \%$ of the patients required endoscopic dilation because of stricture related recurrent dysphagia. Recently, Hirdes, et al., reported the efficacy and safety of sequential Ella BD stent placement in 28 patients with a refractory benign strictures [58]. A total of 59 biodegradable stents were placed in these patients. After initial stent placement patients remained dysphagia free for a period of 90 days, while after six months still $25 \%$ of patients were dysphagia free. After placement of a second biodegradable stent in patients with recurrent stricture formation, patients remained dysphagia free for a median period of 55 days. After six months only $15 \%$ of these patients were still dysphagia free. After a third biodegradable stent placement, the median dysphagia free period was 106 days but none of the patients remained dysphagia free after a period of six months. Major complications occurred in $29 \%, 8 \%$, and $28 \%$ of patients after one, two, and three Ella BD stents respectively. From these studies it can be concluded that a single biodegradable stent is only temporarily effective in the majority of patients. The relatively low radial force and degradable nature of these stents may contribute to early stricture recurrence [67]. Stent placement was also found to be associated with considerable complications, like retrosternal pain and vomiting. However, in selected patients with a refractory benign esophageal stricture, sequential biodegradable stent placement can be an effective alternative to avoid the burden of frequent serial dilations. Further (prospective), studies including larger numbers of patients, and comparing biodegradable stents with fully covered SEMS (or SEPS), are needed. In those studies patient satisfaction and costs should be evaluated besides efficacy and safety.

\section{Optimal duration of stent placement in refractory benign esophageal strictures}

The optimal duration of stent placement for treating refractory benign esophageal strictures is unknown, but likely depends on a number of variables, such as stricture type, severity of the inflammation, stricture length, and stent type. These factors should be evaluated in all patients. The general principle is to leave the stent in place until the inflammation is resolved. In strictures longer than $5 \mathrm{~cm}$ or those due to ischemic injury, dilation for a period of at least 8-16 weeks is recommended. For shorter strictures and other etiologies shorter stenting times can be recommended, but still these strictures may also be refractory. Only fully covered stent designs can safely be removed after a prolonged time of stenting. When partially covered stents are used, repeat endoscopy should be 
performed at 2-4 week intervals to evaluate embedding of the stent in the wall. After biodegradable stent placement, a completely different treatment strategy can be followed. Only when patients treated with a biodegradable stent present with recurrent dysphagia should a repeat endoscopy be performed. In most cases this means that the stent is dissolved and a new stent, either biodegradable or SEMS, can be placed.

\section{Treatment selection (algorithm)}

In absence of evidence based treatment guidelines for patients with dysphagia due to refractory benign esophageal strictures $[68,69]$, an algorithm has been suggested for the therapeutic management of patients with benign dysphagia $[10,70]$, which is shown in Figure 3. Dilation remains the first choice as the least invasive approach with a low complication rate (0.001-0.040 \%) [69]. If the selected approach is not sufficient a next step in the algorithm should be discussed with the patient, i.e., dilation with steroids, incisional therapy for selected strictures, or stent placement. If still refractory, self-bougienage can be proposed to patients with a stenosis in the proximal esophagus [71, 72]. An ultimate step in the management of (refractory), benign esophageal strictures includes surgery, taking into account that even after a surgical solution the risk of stricture formation remains [24-26]. In our experience, the majority of benign strictures can be managed by non-surgical means.

Randomized trials are needed to determine the optimal treatment strategy in patients with refractory and recurrent benign esophageal strictures. One such trial includes a comparison between Savary or balloon dilation therapy and stent placement, either a fully covered SEMS or biodegradable stent, to determine

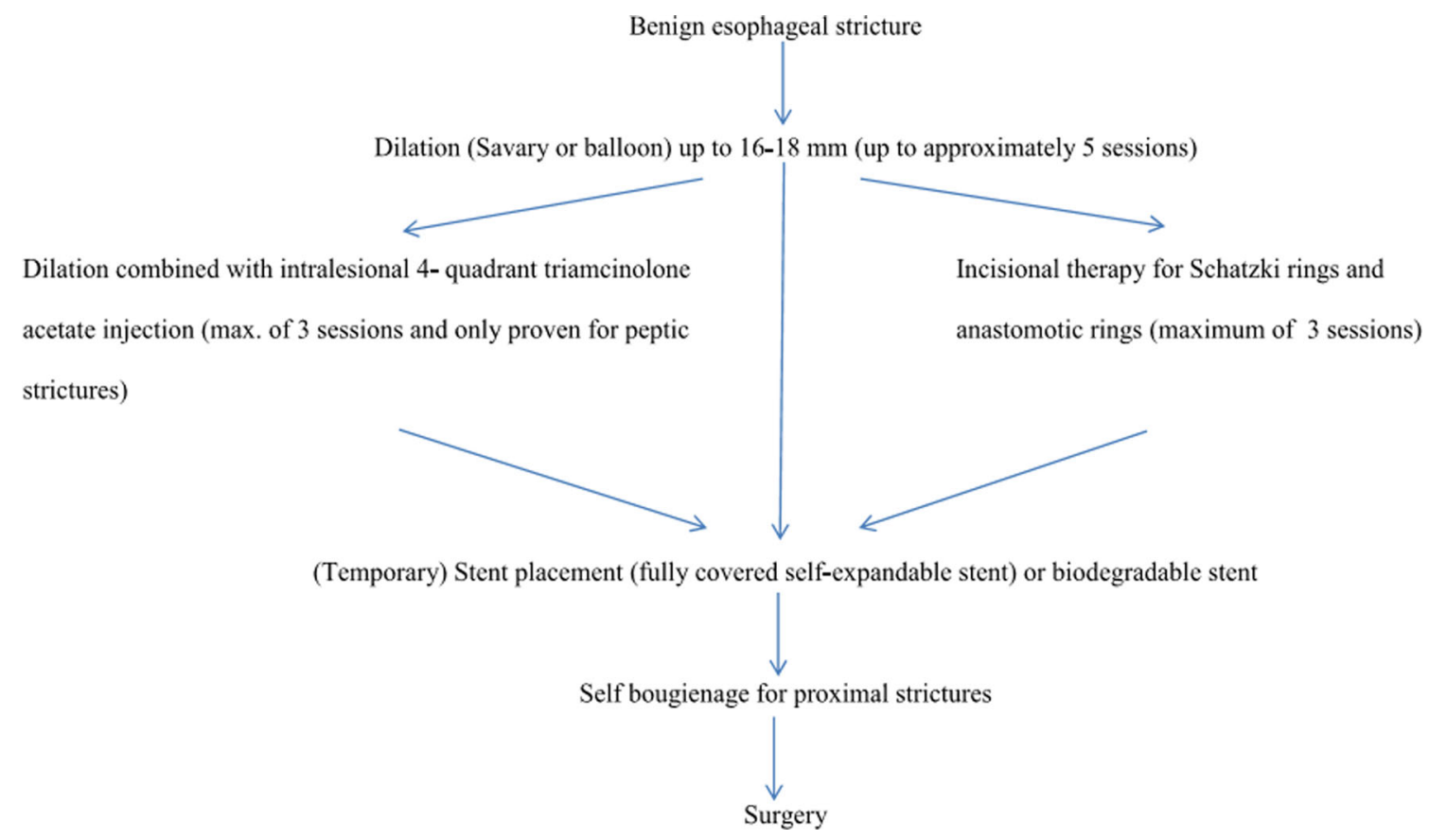

Fig. 3. Recommended treatment scheme for patients with benign esophageal stricture. 


\section{Conclusion}

whether stent placement could be positioned at an earlier stage in the treatment algorithm. Furthermore, biodegradable stents should be compared with fully covered stent designs (as discussed earlier). Finally, the use of a (locally applied) treatment aiming to improve oxygenation (anastomotic strictures), and/or to reduce the inflammatory process in strictures, could be an important step.

The treatment of refractory benign esophageal strictures remains a challenge for clinicians. Dilation of the stricture with Savary or balloon remains the first step. Dilation combined with intra lesional injections with steroids can be considered for peptic stenosis, while incisional therapy is found to be effective for Schatzki rings and anastomotic strictures. After failure of these therapeutic options stent placement can be considered. A final step includes self bougienage or surgery. Following this treatment algorithm means that most patients with a difficult to treat esophageal stricture can be managed without an invasive surgical procedure.

\section{Compliance with Ethics Guidelines}

\section{Conflict of Interest}

Petra G.A. van Boeckel declares that she has no conflict of interest.

Peter D. Siersema declares that he has no conflict of interest.

\section{Human and Animal Rights and Informed Consent}

This article does not contain any studies with human or animal subjects performed by any of the authors.

Open Access This article is distributed under the terms of the Creative Commons Attribution License which permits any use, distribution, and reproduction in any medium, provided the original author(s) and the source are credited.

\section{References and Recommended Reading}

Papers of particular interest, published recently, have been highlighted as:

- Of importance

$\bullet \quad$ Of major importance

1. Marks RD, Richter JE. Peptic strictures of the esophagus. 5. Am J Gastroenterol. 1993;88(8):1160-73.

2. Patterson DJ, Graham DY, Smith JL, et al. Natural history of benign esophageal stricture treated by dilatation. Gastroenterology. 1983;85(2):346-50.

3. Eisen GM, Baron TH, Dominitz JA, et al. Complications of upper GI endoscopy. Gastrointest Endosc. 2002;55(7):784-93.

4. Pereira-Lima JC, Ramires RP, Zamin Jr I, Cassal AP, Marroni CA, Mattos AA. Endoscopic dilation of benign esophageal strictures: report on 1043 procedures. Am J Gastroenterol. 1999;94(6):1497-501.
5. Shah JN. Benign refractory esophageal strictures: widening the endoscopist's role. Gastrointest Endosc. 2006;63(1):164-7.

6. $\quad$ Saeed ZA, Ramirez FC, Hepps KS, et al. An objective end point for dilation improves outcome of peptic esophageal strictures: a prospective randomized trial. Gastrointest Endosc. 1997;45(5):354-9.

7. Lew RJ, Kochman ML. A review of endoscopic methods of esophageal dilation. J Clin Gastroenterol. 2002;35(2):117-26.

8.• Kochman ML, McClave SA, Boyce HW. The refractory and the recurrent esophageal stricture: a definition. Gastrointest Endosc. 2005;62(3):474-5. 
This article describes the definition of refractory and the recurrent stricture.

9. Siersema PD. Treatment options for esophageal strictures. Nat Clin Pract Gastroenterol Hepatol. 2008;5(3):142-52.

10. Siersema PD, de Wijkerslooth LR. Dilation of refractory benign esophageal strictures. Gastrointest Endosc. 2009;70(5):1000-12.

11. Scolapio JS, Pasha TM, Gostout CJ, et al. A randomized prospective study comparing rigid to balloon dilators for benign esophageal strictures and rings. Gastrointest Endosc. 1999;50(1):13-7.

12. Cox JG, Winter RK, Maslin SC, et al. Balloon or bougie for dilatation of benign oesophageal stricture? An interim report of a randomised controlled trial. Gut. 1988;29(12):1741-7.

13. Saeed ZA, Winchester CB, Ferro PS, Michaletz PA, Schwartz JT, Graham DY. Prospective randomized comparison of polyvinyl bougies and through-thescope balloons for dilation of peptic strictures of the esophagus. Gastrointest Endosc. 1995;41(3):189-95.

14. Yamamoto H, Hughes Jr RW, Schroeder KW, Viggiano TR, DiMagno EP. Treatment of benign esophageal stricture by Eder-Puestow or balloon dilators: a comparison between randomized and prospective nonrandomized trials. Mayo Clin Proc. 1992;67(3):228-36.

15. Boyce HW. Dilation of difficult benign esophageal strictures. Am J Gastroenterol. 2005;100(4):744-5.

16. Ashcraft KW, Holder TM. The experimental treatment of esophageal strictures by intralesional steroid injections. J Thorac Cardiovasc Surg. 1969;58(5):685-91.

17. Holder TM, Ashcraft KW, Leape L. The treatment of patients with esophageal strictures by local steroid injections. J Pediatr Surg. 1969;4(6):646-53.

18. Kochhar R, Ray JD, Sriram PV, Kumar S, Singh K. Intralesional steroids augment the effects of endoscopic dilation in corrosive esophageal strictures. Gastrointest Endosc. 1999;49(4 Pt 1):509-13.

19. Kochhar R, Makharia GK. Usefulness of intralesional triamcinolone in treatment of benign esophageal strictures. Gastrointest Endosc. 2002;56(6):829-34.

20. Camargo MA, Lopes LR, Grangeia TA, Andreollo NA, Brandalise NA. Use of corticosteroids after esophageal dilations on patients with corrosive stenosis: prospective, randomized and double-blind study. Rev Assoc Med Bras. 2003;49(3):286-92.

21. Dunne D, Rupp T, Rex D. Five year follow up of prospective randomized trial of savory dilations with or without intralesional steroids of benign gastrooesophageal reflux strictures. Gastroenterology. 1999. Ref Type: Abstract

22. Ramage Jr JI, Rumalla A, Baron TH, et al. A prospective, randomized, double-blind, placebo-controlled trial of endoscopic steroid injection therapy for recalcitrant esophageal peptic strictures. Am J Gastroenterol. 2005; 100(11):2419-25.

23. Hirdes MM, van Hooft JE, Koornstra JJ, et al. Endoscopic corticosteroid injections do not reduce dysphagia after endoscopic dilation therapy in patients with benign esophagogastric anastomotic strictures. Clin Gastroenterol Hepatol. 2013;11(7):795-801.

Prospective trial showing that endoscopic corticosteroid injections do not reduce dysphagia after dilation in patients with benign esophagogastric anastomotic strictures.

24. Honkoop P, Siersema PD, Tilanus HW, Stassen LP, Hop WC, van Blankenstein M. Benign anastomotic strictures after transhiatal esophagectomy and cervical esophagogastrostomy: risk factors and management. J Thorac Cardiovasc Surg. 1996;111(6):1141-6.

25. Burdick JS, Venu RP, Hogan WJ. Cutting the defiant lower esophageal ring. Gastrointest Endosc. 1993;39(5):616-9.

26. Disario JA, Pedersen PJ, Bichis-Canoutas C, Alder SC, Fang JC. Incision of recurrent distal esophageal (Schatzki) ring after dilation. Gastrointest Endosc. 2002;56(2):244-8.

27. Brandimarte G, Tursi A. Endoscopic treatment of benign anastomotic esophageal stenosis with electrocautery. Endoscopy. 2002;34(5):399-401.

28. Hagiwara A, Togawa T, Yamasaki J, Shirasu M, Sakakura C, Yamagishi H. Endoscopic incision and balloon dilatation for cicatricial anastomotic strictures. Hepatogastroenterol. 1999;46(26):997-9.

29. Pross $M$, Manger T, Lippert H. Combination of diathermy and argon plasma coagulation in treatment of cicatricial esophageal stenoses. Zentralbl Chir. 1998;123(10):1145-7.

30. Schubert D, Kuhn R, Lippert H, Pross M. Endoscopic treatment of benign gastrointestinal anastomotic strictures using argon plasma coagulation in combination with diathermy. Surg Endosc. 2003;17(10):157982.

31. Hordijk ML, Siersema PD, Tilanus HW, Kuipers EJ. Electrocautery therapy for refractory anastomotic strictures of the esophagus. Gastrointest Endosc. 2006;63(1):157-63.

32. Lee TH, Lee SH, Park JY, et al. Primary incisional therapy with a modified method for patients with benign anastomotic esophageal stricture. Gastrointest Endosc. 2009;69(6):1029-33.

33. Hordijk ML, van Hooft JE, Hansen BE, Fockens P, Kuipers EJ. A randomized comparison of electrocautery incision with Savary bougienage for relief of anastomotic gastroesophageal strictures. Gastrointest Endosc. 2009;70(5):849-55.

34. Pungpapong S, Raimondo M, Wallace MB, Woodward TA. Problematic esophageal stricture: an emerging indication for self-expandable silicone stents. Gastrointest Endosc. 2004;60(5):842-5.

35. Wadhwa RP, Kozarek RA, France RE, et al. Use of selfexpandable metallic stents in benign GI diseases. Gastrointest Endosc. 2003;58(2):207-12.

36. Repici A, Vleggaar FP, Hassan C, et al. Efficacy and safety of biodegradable stents for refractory benign esophageal strictures: the BEST (Biodegradable Esophageal Stent) study. Gastrointest Endosc. 2010;72(5):927-34. 
37. Lee JG, Hsu R, Leung JW. Are self-expanding metal mesh stents useful in the treatment of benign esophageal stenoses and fistulas? An experience of four cases. Am J Gastroenterol. 2000;95(8):1920-5.

38. Fiorini A, Fleischer D, Valero J, Israeli E, Wengrower D, Goldin E. Self-expandable metal coil stents in the treatment of benign esophageal strictures refractory to conventional therapy: a case series. Gastrointest Endosc. 2000;52(2):259-62.

39. Cwikiel W, Willen R, Stridbeck H, Lillo-Gil R, von Holstein CS. Self-expanding stent in the treatment of benign esophageal strictures: experimental study in pigs and presentation of clinical cases. Radiology. 1993;187(3):667-71.

40. Song HY, Jung HY, Park SI, et al. Covered retrievable expandable nitinol stents in patients with benign esophageal strictures: initial experience. Radiology. 2000;217(2):551-7.

41. Tan BS, Kennedy C, Morgan R, Owen W, Adam A. Using uncovered metallic endoprostheses to treat recurrent benign esophageal strictures. AJR Am J Roentgenol. 1997;169(5):1281-4.

42. Cheng YS, Li MH, Chen WX, Chen NW, Zhuang QX, Shang KZ. Temporary partially-covered metal stent insertion in benign esophageal stricture. World J Gastroenterol. 2003;9(10):2359-61.

43. Mukherjee S, Kaplan DS, Parasher G, Sipple MS. Expandable metal stents in achalasia-is there a role? Am J Gastroenterol. 2000;95(9):2185-8.

44. Song HY, Park SI, Jung HY, et al. Benign and malignant esophageal strictures: treatment with a polyurethanecovered retrievable expandable metallic stent. Radiology. 1997;203(3):747-52.

45. Siersema PD. Stenting for benign esophageal strictures. Endoscopy. 2009;41(4):363-73.

46. Hirdes MM, Vleggaar FP, Siersema PD. Stent placement for esophageal strictures: an update. Expert Rev Med Devices. 2011;8(6):733-55.

47. Mayoral W, Fleischer D, Salcedo J, Roy P, Al-Kawas F, Benjamin S. Nonmalignant obstruction is a common problem with metal stents in the treatment of esophageal cancer. Gastrointest Endosc. 2000;51(5):556-9.

48. Eloubeidi MA, Lopes TL. Novel removable internally fully covered self-expanding metal esophageal stent: feasibility, technique of removal, and tissue response in humans. Am J Gastroenterol. 2009;104(6):1374-81.

49. Hirdes MM, Siersema PD, Houben MH, Weusten BL, Vleggaar FP. Stent-in-stent technique for removal of embedded esophageal self-expanding metal stents. Am J Gastroenterol. 2011;106(2):286-93.

Article descibes how to safely remove a partly covered metal stent.

50. Johnsson E, Lundell L, Liedman B. Sealing of esophageal perforation or ruptures with expandable metallic stents: a prospective controlled study on treatment efficacy and limitations. Dis Esophagus.

2005;18(4):262-6.

51. Uitdehaag MJ, van Hooft JE, Verschuur EM, et al. A fully-covered stent (Alimaxx-E) for the palliation of malignant dysphagia: a prospective follow-up study. Gastrointest Endosc. 2009;70(6):1082-9.

52. Bakken JC, Wong Kee Song LM, de Groen PC, Baron $\mathrm{TH}$. Use of a fully covered self-expandable metal stent for the treatment of benign esophageal diseases. Gastrointest Endosc. 2010;72(4):712-20.

53. Eloubeidi MA, Talreja JP, Lopes TL, Al-Awabdy BS, Shami VM, Kahaleh M. Success and complications associated with placement of fully covered removable self-expandable metal stents for benign esophageal diseases (with videos). Gastrointest Endosc. 2011;73(4):673-81.

54. Hirdes MM, Siersema PD, Vleggaar FP. A new fully covered metal stent for the treatment of benign and malignant dysphagia: a prospective follow-up study. Gastrointest Endosc. 2012;75(4):712-8.

55. Repici A, Hassan C, Sharma P, Conio M, Siersema P. Systematic review: the role of self-expanding plastic stents for benign oesophageal strictures. Aliment Pharmacol Ther. 2010;31(12):1268-75.

56. Ham YH, Kim GH. Plastic and biodegradable stents for complex and refractory benign esophageal strictures. Clin Endosc. 2014;47(4):295-300.

57. van Boeckel PG, Vleggaar FP, Siersema PD. A comparison of temporary self-expanding plastic and biodegradable stents for refractory benign esophageal strictures. Clin Gastroenterol Hepatol. 2011;9(8):653-9.

First article making a direct head to head comparison between a self expanding plastic and biodegradable stent for refractory benign esophageal strictures.

58. Hirdes MM, Siersema PD, van Boeckel PG, Vleggaar FP. Single and sequential biodegradable stent placement for refractory benign esophageal strictures: a prospective follow-up study. Endoscopy. 2012;44(7):649-54.

59. Saito Y, Tanaka T, Andoh A, et al. Novel biodegradable stents for benign esophageal strictures following endoscopic submucosal dissection. Dig Dis Sci. 2008;53(2):330-3.

60. Saito Y, Tanaka T, Andoh A, et al. Usefulness of biodegradable stents constructed of poly-l-lactic acid monofilaments in patients with benign esophageal stenosis. World J Gastroenterol. 2007;13(29):397780 .

61. Tanaka T, Takahashi M, Nitta N, et al. Newly developed biodegradable stents for benign gastrointestinal tract stenoses: a preliminary clinical trial. Digestion. 2006;74(3-4):199-205.

62. Cerna $\mathrm{M}$, Kocher $\mathrm{M}$, Valek V, et al. Covered biodegradable stent: new therapeutic option for the management of esophageal perforation or anastomotic leak. Cardiovasc Intervent Radiol. 2011;34(6):126771.

63. Griffiths EA, Gregory CJ, Pursnani KG, Ward JB, Stockwell RC. The use of biodegradable (SX-ELLA) oesophageal stents to treat dysphagia due to benign and malignant oesophageal disease. Surg Endosc. 2012;26(8):2367-75. 
64. Ibrahim M, Vandermeeren A, van Mael V, Deprez $\mathrm{P}$. Belgian multicenter study experience with biodegradable ella-stent in benign strictures of the digestive tract. Endoscopy. 2010. Ref Type: Abstract

65. Stivaros SM, Williams LR, Senger C, Wilbraham L, Laasch HU. Woven polydioxanone biodegradable stents: a new treatment option for benign and malignant oesophageal strictures. Eur Radiol. 2010;20(5):1069-72.

66. van Hooft JE, van Berge Henegouwen MI, Rauws EA, Bergman JJ, Busch OR, Fockens P. Endoscopic treatment of benign anastomotic esophagogastric strictures with a biodegradable stent. Gastrointest Endosc. 2011;73(5):1043-7.

67. Hirdes MM, Vleggaar FP, de Beule M, Siersema PD. In vitro evaluation of the radial and axial force of selfexpanding esophageal stents. Endoscopy. 2013;45(12):997-1005.
68. ASGE. American Society for Gastrointestinal Endoscopy. Technology Assessment Status Evaluation: stents for gastrointestinal strictures. May, 1997. Gastrointest Endosc. 1998;47(6):588-93.

69. Spechler SJ. AGA technical review on treatment of patients with dysphagia caused by benign disorders of the distal esophagus. Gastroenterology. 1999;117(1):23354.

70. de Wijkerslooth LR, Vleggaar FP, Siersema PD. Endoscopic management of difficult or recurrent esophageal strictures. Am J Gastroenterol. 2011;106(12):2080-91.

71. Bapat RD, Bakhshi GD, Kantharia CV, Shirodkar SS, Iyer AP, Ranka S. Self-bougienage: long-term relief of corrosive esophageal strictures. Indian J Gastroenterol. 2001;20(5):180-2.

72. Dzeletovic I, Fleischer DE. Self-dilation for resistant, benign esophageal strictures. Am J Gastroenterol. 2010;105(10):2142-3. 